www.jmscr.igmpublication.org

Impact Factor (SJIF): 6.379

Index Copernicus Value: 71.58

ISSN (e)-2347-176x ISSN (p) 2455-0450

crossrefDOI: https://dx.doi.org/10.18535/jmscr/v6i7.143

Journal Of Medical Science And Clinical Research

IGM Publication

An official Publication of IGM Publication

\title{
A Comparative Study on the Effect of Tobacco Smoke and Tobbaco Salivary Extract on Serum Lipid Profile
}

\author{
Authors \\ Manju Pandey*', Shruti Satish Vadke ${ }^{2}$, Gajraj Singh Yadav ${ }^{3}$, D. D. Deol ${ }^{4}$ \\ ${ }^{1,2,4}$ Department of Gen. Medicine, ${ }^{3}$ Department of Biochemistry \\ National Institute of Medical Science and Research, A Constituent Institute of NIMS University \\ Jaipur-303121 (Rajasthan) India \\ *Corresponding Author \\ Manju Pandey \\ Email: manju.pandey4@gmail.com
}

\begin{abstract}
Background: Which form of tobacco use has more adverse effects on lipid profile?

Objective: To identify the effect of tobacco use as smoking or chewing is associated with greater adverse effects on various components of serum lipid profile.

Materials and Methods: The study was conducted on 400 subjects $(200$ tobacco smoker \& 200 tobacco chewer) admitted in wards and attending OPD under department of medicine, NIMS medical college \& hospital Jaipur and 400 controls. S. Cholesterol by enzymatic end point CHOD/PAP method. S. Triglyceride by enzymatic glycerol phosphate oxidase/peroxidase method S. HDL by homogenous enzyme direct assay. Statistical analysis was done using SPSS Ver. 20 (IBM SPSS Statistical Inc., Chicago, Illinois, USA). The independent $t$ test and ANOVA with post hoc Bonferroni test were used for comparison of all clinical indicators. Chi - square test used for qualitative data whenever two or more than two groups were used to compare. Level of significance was set at $P \leq 0.05$.

Results: Mean value of TC, TG, LDL, VLDL, of tobacco smokers and tobacco chewers were found significantly higher $(P<0.001)$ as compared to mean values of these parameters amongst non smokers, non chewers. The mean HDL amongst tobacco smokers was significantly lower as compared to controls.

Conclusion: Tobacco is the major preventable risk factor for atherosclerosis related clinical events like coronary artery disease. Cigarette smoking had greater adverse effects on the serum lipid profile as compared to bidi smoking and tobacco chewing thereby increasing the cardiovascular risk.

Keywords: Tobacco, Lipid profile, Cigarette smoke, Tobacco Chewing.
\end{abstract}

\section{Introduction}

Tobacco was introduced to India in the $17^{\text {th }}$ century $^{[1]}$. Moreover, India is third largest tobacco producer and its product consumer, after China and U.S.A. in the world. The main form of tobacco use in developed countries is high grade smoking (Cigarette), while low grade sucking
(Bidi), chewing and snuffing are common in developing countries ${ }^{[2]}$. There is a wide variety of tobacco products found in India, consumption of tobacco in its various forms is the major and single most preventable risk factor for atherosclerosis related clinical events ${ }^{[3]}$. All forms of tobacco use are reported to carry serious health 
consequences, an important one being dyslipidemia. According to National Cholesterol Education Programme: Adult Treatment Panel-III (NCEP: ATP-III) ${ }^{[4]}$ dyslipidemia is defined as follows:

> Hypercholesterolemia: Serum cholesterol levels $>200 \mathrm{mg} / \mathrm{dl}$

$>$ Hypertriglyceridemia: Serum triglyceride levels $>150 \mathrm{mg} / \mathrm{dl}$

$>$ Low HDL cholesterol: HDL cholesterol levels $<40 \mathrm{mg} / \mathrm{dl}$ for men and $<50 \mathrm{mg} / \mathrm{dl}$ for women.

$>$ High LDL cholesterol: High LDL cholesterol LDL cholesterol levels >130 $\mathrm{mg} / \mathrm{dl}$ (Friedewald equation)

$>$ Isolated hypercholesterolemia: Serum cholesterol $\geq 200 \mathrm{mg} / \mathrm{dl}$ and triglyceride $<150 \mathrm{mg} / \mathrm{dl}$

$>$ Isolated hypertriglyceridemia: Serum triglycerides $\geq 150 \mathrm{mg} / \mathrm{dl}$ and cholesterol $<200 \mathrm{mg} / \mathrm{dl}$

Several studies provide the evidence that tobacco is strongly associated with altering the normal status of lipid profile. There is still much controversy about which parts of lipid are mainly altered in response to tobacco use. In a worldwide report, it was found that male smoking far exceeds female smoking, while a smaller gender difference occur in high-income countries.

\section{Material and Methods}

A cross sectional study was carried out in the department of medicine, NIMS medical college and hospital, Jaipur (INDIA). Subjects were both male and female of age more than 18 years and less than 60 years. All were admitted in wards or attending OPD under the department of medicine. Total 400 subjects were taken in two groups 200 tobacco chewing and 200 tobacco smoking. Blood sample was collected by venipuncture in standard aseptic condition. Serum was separated and subjected to estimation biochemical parameters on fully automatic analyzer (Trivitron Nano lab 150). Lipid profile estimation was done using following methods:
$>$ S. Cholestrol by enzymatic end point CHOD/PAP method ${ }^{[5]}$.

$>$ S. Triglyceride by enzymatic glycerol phosphate oxidase / peroxidase method ${ }^{[6]}$.

$>$ S. HDLc by homogenous enzyme direct assay ${ }^{[7]}$.

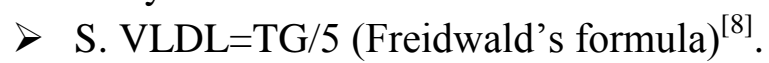

$>$ S.LDL=Total Cholestrol-(HDL+VLDL) (Freidwald's formula) ${ }^{[8]}$.

The data was analyzed using SPSS version 20 (IBM SPSS Statistics Inc., Chicago, Illinois, USA) windows software program. The variable was assessed for normally using the Kolmogorov Smirnov test. Descriptive statistics included computation of percentages, means and standard deviation. The independent (unpaired) $t$ test ( for quantitative data within three groups) and analysis of variance (ANOVA) (for quantitative data within three groups) with post hoc Bonferroni test ( to make more intra - group comparison) were used for comparison of all clinical indicators Chi square test used for qualitative data whenever two or more than two groups were used to compare. Level of significance was set at $\mathrm{P}<0.05$.

\section{Result}

TC: Mean TC amongst cigarette smokers was $226.26 \pm 59.54 \mathrm{mg} / \mathrm{dl}$ as compared to mean TC among controls was $155.10 \pm 39.28 \mathrm{mg} / \mathrm{dl}$. There was a statistically significant difference between mean TC for cigarette smokers and controls as $\mathrm{P}<$ 0.001. Mean TC amongst bidi smokers was $190.73 \pm 29.59 \mathrm{mg} / \mathrm{dl}$ as compared to mean TC among controls was $155.10 \pm 39.28 \mathrm{mg} / \mathrm{dl}$ with mean difference of 35.63 . There was a statistically significant difference between mean TC for bidi smokers and controls as $\mathrm{P}<0.001$. Mean TC amongst tobacco chewers was $187.51 \pm 40.46 \mathrm{mg} / \mathrm{dl}$ as compared to mean TC among controls was $155.10 \pm 39.28 \mathrm{mg} / \mathrm{dl}$ with mean difference of 32.41. There was a statistically significant difference between mean TC for tobacco chewers and controls as $\mathrm{P}<0.001$ [Table-1, Fig-1,2,3].

TG: Mean TG among cigarette smokers was $198.85 \pm 120.84 \mathrm{mg} / \mathrm{dl}$ as compared to mean TG 
against controls was $134.31 \pm 61.67 \mathrm{mg} / \mathrm{dl}$. Mean TG difference between cigarette smokers and controls was highly significant as $\mathrm{P}<0.001$. Mean TG amongst bidi smokers was $172.56 \pm 75.33 \mathrm{mg} / \mathrm{dl}$, as compared to mean $\mathrm{TC}$ against control was 134.31 \pm 61.67 . Mean TG difference of 38.25 between bidi smokers and controls was highly significant as $\mathrm{P}<0.001$. Mean TG amongst tobacco chewers was $168.53 \pm 80.46 \mathrm{mg} / \mathrm{dl}$, as compared to mean $\mathrm{TC}$ against control was 134.31 6 61.67. Mean TG difference of 34.15 between tobacco chewers and controls was highly significant as $\mathrm{P}<0.001$ [Table1, Fig-1,2,3].

HDL: Mean HDL amongst cigarette smokers was $36.13 \pm 1.08 \mathrm{mg} / \mathrm{dl}$ as compared to mean HDL amongst controls was $39.89 \pm 8.48 \mathrm{mg} / \mathrm{dl}$. The mean HDL amongst cigarette smokers was significantly decreased as compared to mean HDL amongst controls as $\mathrm{P}$ was 0.002 . Mean HDL amongst bidi smokers was $36.13 \pm 1.08 \mathrm{mg} / \mathrm{dl}$ as compared to mean HDL amongst controls was $39.89 \pm 8.48 \mathrm{mg} / \mathrm{dl}$ with mean difference of 3.58 between these two groups. The mean HDL amongst bidi smokers was significantly decreased as compared to mean HDL amongst controls as $\mathrm{P}$ $<0.001$ [Table-1, Fig-1,2,3].

Mean HDL amongst tobacco chewers was $35.95 \pm 7.901 \mathrm{mg} / \mathrm{dl}$ as compared to mean HDL amongst controls was $39.89 \pm 8.48 \mathrm{mg} / \mathrm{dl}$ with mean difference of 3.94 between these two groups. The mean HDL amongst tobacco chewers was significantly decreased as compared to mean HDL amongst controls as $\mathrm{P}<0.001$.
LDL: Mean LDL amongst cigarette smokers was $142.78 \pm 53.26 \mathrm{mg} / \mathrm{dl}$ as compared to mean LDL amongst controls was $89.5 \pm 34.33 \mathrm{mg} / \mathrm{dl}$. Mean LDL difference between cigarette smokers and controls was highly significant as $\mathrm{P}$ was 0.001 . Mean LDL amongst bidi smokers was $115.91 \pm 26.705 \mathrm{mg} / \mathrm{dl}$ as compared to mean LDL amongst controls was $89.5 \pm 34.33 \mathrm{mg} / \mathrm{dl}$. Mean LDL difference between bidi smokers and controls was 26.41 which was highly significant as $\mathrm{P}<0.001$. Mean LDL amongst tobacco chewers was $112.92 \pm 37.19 \mathrm{mg} / \mathrm{dl}$ as compared to mean LDL amongst controls was $89.5 \pm 34.33 \mathrm{mg} / \mathrm{dl}$. Mean LDL difference between tobacco chewers and controls was 23.42 which was highly significant as $\mathrm{P}<0.001[$ Table-1, Fig$1,2,3]$.

VLDL: Mean VLDL amongst cigarette smokers was $39.89 \pm 24.109 \mathrm{mg} / \mathrm{dl}$ as compared to mean VLDL amongst controls was $27.09 \pm 12.85 \mathrm{mg} / \mathrm{dl}$. Mean VLDL difference between two groups was highly significant as $\mathrm{P}<0.001$.Mean VLDL amongst bidi smokers was $34.56 \pm 15.03 \mathrm{mg} / \mathrm{dl}$ as compared to mean VLDL amongst controls was $27.09 \pm 12.85 \mathrm{mg} / \mathrm{dl}$. Mean VLDL difference between two groups was 7.46 which was highly significant as $\mathrm{P}<0.001$. Mean VLDL amongst tobacco chewers was $33.78 \pm 16.07 \mathrm{mg} / \mathrm{dl}$ as compared to mean VLDL amongst controls was $27.09 \pm 12.85 \mathrm{mg} / \mathrm{dl}$. Mean VLDL difference between two groups was 6.69 which was highly significant as $\mathrm{P}<0.001$ [Table-1, Fig-1,2,3].

Table-1: Comparison of lipid profile between cigarette smokers, bidi smokers and tobacco chewers with respect to control

\begin{tabular}{|c|c|c|c|c|c|c|c|}
\hline Tobacco Users & \multicolumn{2}{|c|}{ Lipid Profile } & $\mathrm{N}$ & Mean & SD & Mean Difference & P Value \\
\hline \multirow{10}{*}{$\begin{array}{l}\text { Cigarette } \\
\text { Smokers }\end{array}$} & \multirow{2}{*}{ TC } & Cont. & 400 & 155.10 & 39.28 & \multirow{2}{*}{71.16} & \multirow[t]{2}{*}{0.001} \\
\hline & & Sub. & 80 & 226.26 & 59.54 & & \\
\hline & \multirow[t]{2}{*}{ TG } & Cont. & 400 & 134.31 & 61.67 & \multirow[t]{2}{*}{64.53} & \multirow[t]{2}{*}{0.001} \\
\hline & & Sub. & 80 & 198.85 & 120.84 & & \\
\hline & \multirow[t]{2}{*}{ HDL } & Cont. & 400 & 39.89 & 8.48 & \multirow[t]{2}{*}{3.76} & \multirow[t]{2}{*}{0.002} \\
\hline & & Sub. & 80 & 36.13 & 1.08 & & \\
\hline & \multirow[t]{2}{*}{ LDL } & Cont. & 400 & 89.5 & 34.33 & \multirow[t]{2}{*}{53.28} & \multirow[t]{2}{*}{0.001} \\
\hline & & Sub. & 80 & 142.78 & 53.26 & & \\
\hline & \multirow[t]{2}{*}{ VLDL } & Cont. & 400 & 27.09 & 12.85 & \multirow[t]{2}{*}{12.79} & \multirow[t]{2}{*}{0.001} \\
\hline & & Sub. & 80 & 39.89 & 24.109 & & \\
\hline
\end{tabular}




\begin{tabular}{|c|c|c|c|c|c|c|c|}
\hline \multirow{10}{*}{$\begin{array}{l}\text { Bidi } \\
\text { Smokers }\end{array}$} & \multirow[t]{2}{*}{ TC } & Cont. & 400 & 155.10 & 39.28 & \multirow[t]{2}{*}{35.63} & \multirow[t]{2}{*}{0.001} \\
\hline & & Sub. & 120 & 190.73 & 29.59 & & \\
\hline & \multirow[t]{2}{*}{ TG } & Cont. & 400 & 134.31 & 61.67 & \multirow[t]{2}{*}{38.25} & \multirow[t]{2}{*}{0.001} \\
\hline & & Sub. & 120 & 172.56 & 75.33 & & \\
\hline & \multirow[t]{2}{*}{ HDL } & Cont. & 400 & 39.89 & 8.48 & \multirow[t]{2}{*}{3.58} & \multirow[t]{2}{*}{0.001} \\
\hline & & Sub. & 120 & 36.31 & 8.07 & & \\
\hline & \multirow{2}{*}{ LDL } & Cont. & 400 & 89.5 & 34.33 & \multirow[t]{2}{*}{26.41} & \multirow[t]{2}{*}{0.001} \\
\hline & & Sub. & 120 & 115.91 & 26.705 & & \\
\hline & \multirow[t]{2}{*}{ VLDL } & Cont. & 400 & 27.09 & 12.85 & \multirow[t]{2}{*}{7.46} & \multirow[t]{2}{*}{0.001} \\
\hline & & Sub. & 120 & 34.56 & 15.03 & & \\
\hline \multirow{10}{*}{ Chewers } & \multirow[t]{2}{*}{ TC } & Cont. & 400 & 155.10 & 39.28 & \multirow[t]{2}{*}{32.41} & \multirow[t]{2}{*}{0.001} \\
\hline & & Sub. & 200 & 187.51 & 40.86 & & \\
\hline & \multirow[t]{2}{*}{ TG } & Cont. & 400 & 134.31 & 61.67 & \multirow[t]{2}{*}{34.21} & \multirow[t]{2}{*}{0.001} \\
\hline & & Sub. & 200 & 168.53 & 80.46 & & \\
\hline & \multirow[t]{2}{*}{ HDL } & Cont. & 400 & 39.89 & 8.48 & \multirow[t]{2}{*}{3.94} & \multirow[t]{2}{*}{0.001} \\
\hline & & Sub. & 200 & 35.95 & 7.901 & & \\
\hline & \multirow[t]{2}{*}{ LDL } & Cont. & 400 & 89.5 & 34.33 & \multirow[t]{2}{*}{23.42} & \multirow[t]{2}{*}{0.001} \\
\hline & & Sub. & 200 & 112.92 & 37.19 & & \\
\hline & \multirow[t]{2}{*}{ VLDL } & Cont. & 400 & 27.09 & 12.85 & \multirow[t]{2}{*}{6.69} & \multirow[t]{2}{*}{0.001} \\
\hline & & Sub. & 200 & 33.78 & 16.07 & & \\
\hline
\end{tabular}

Fig-1: Comparison of lipid profile between cigarette smokers and control

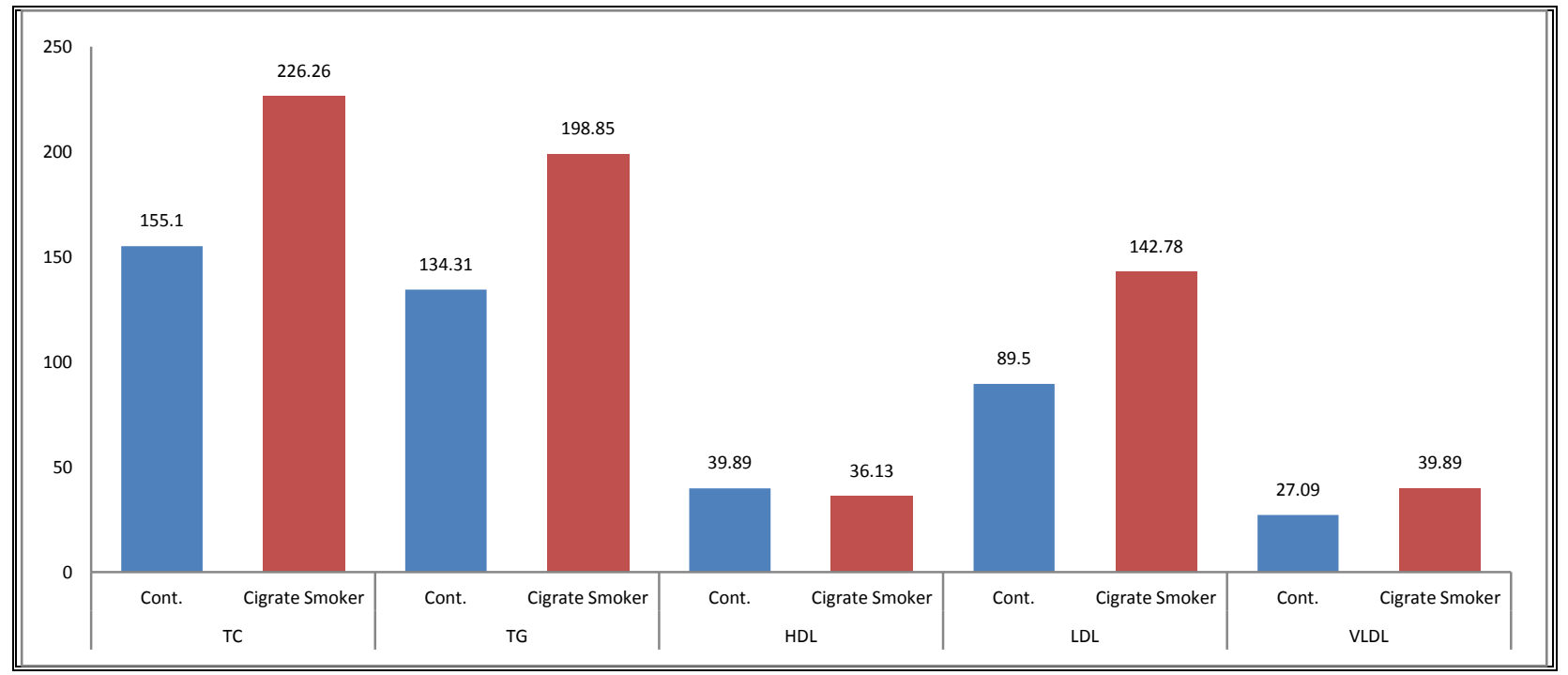

Fig-2: Comparison of lipid profile between bidi smokers and control

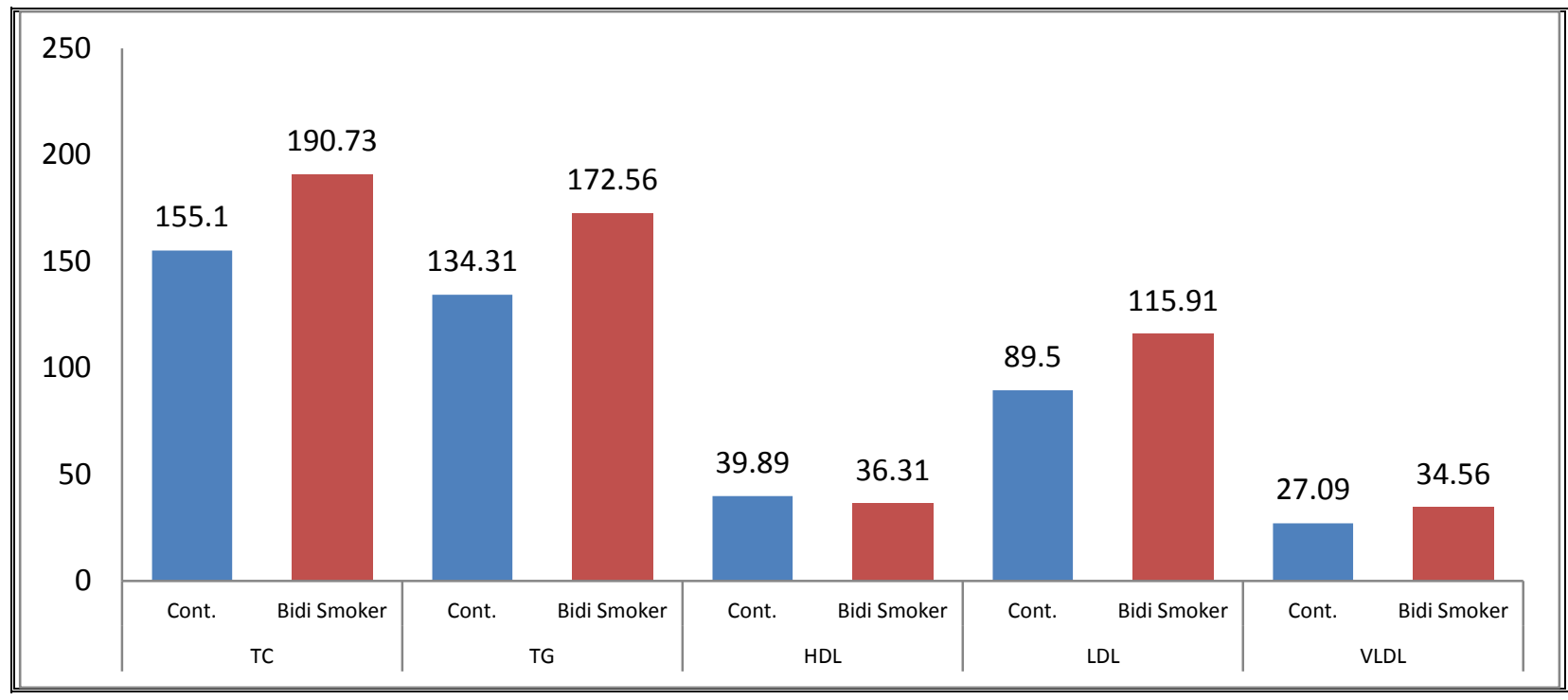


Fig-3: Comparison of lipid profile between tobacco chewers and control

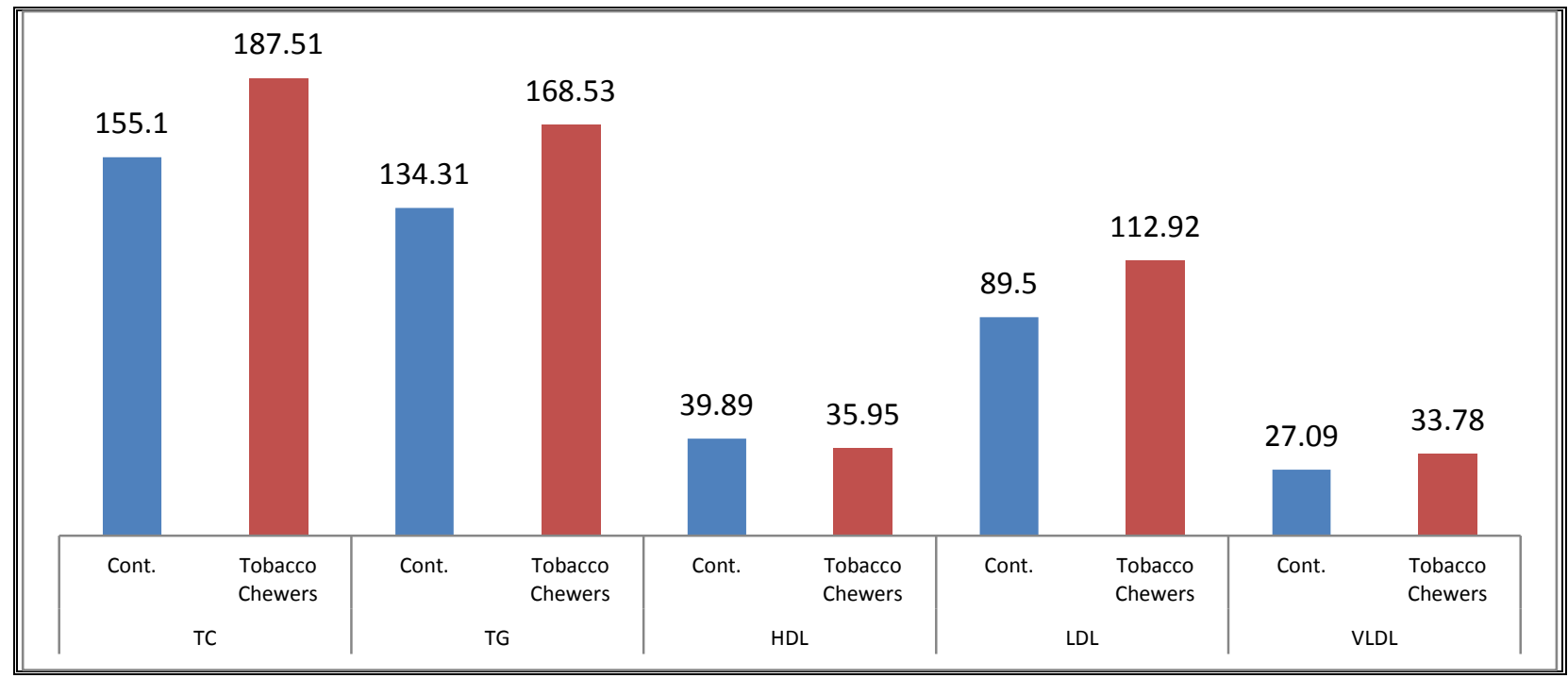

Fig-4: Comparison of lipid profile between Cigarette smokers, bidi smokers and tobacco chewers.

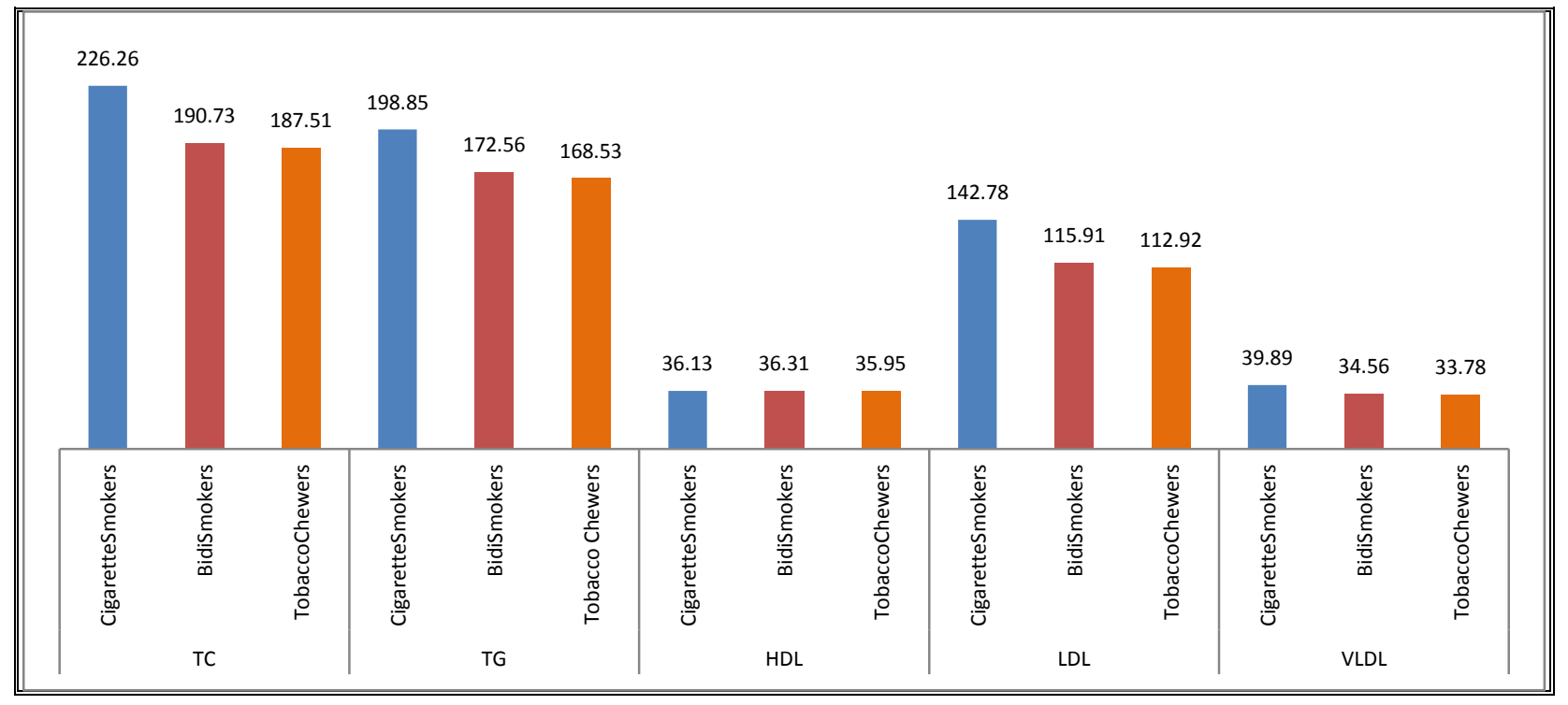

\section{Discussion}

Awareness of correlation between smoking and cardiovascular disease remains low in many parts of the world. Tobacco smoking or chewing is a major risk factor cardiovascular morbidity and mortality $^{[9]}$. Smoking is estimated to cause $10 \%$ of cardiovascular disease (CVD) and is second leading cause of CVD, after high blood pressure. The risk for coronary heart disease is $25 \%$ higher in female smokers than in male smokers ${ }^{[10]}$. Chewing tobacco more than doubles the risk of heart attack and tobacco smoking and chewing may lead to alteration of the normal plasma lipoprotein pattern. In this study we have found that among tobacco smokers mean TC, TG,
LDL, VLDL, were significantly higher as compared to mean values of these parameters amongst non smokers, non chewers. The mean HDL amongst tobacco smokers was significantly lower as compared to controls. In other study it was found TC,TG,LSL, VLDL were higher in smokers as compared to non smokers $(\mathrm{P}<0.001)$. HDL was lower in smokers as compared to in non smokers $(\mathrm{P}<0.001)^{[11]}$. Our study was in agreement with studies of Ketan Patel et $\mathrm{al}^{[12]}$ and Srinivasa Rao et al ${ }^{[13]}$.

\section{Conclusion}

Tobacco is the major preventable risk factor for atherosclerotic related clinical events like 
coronary artery disease. Cigarette smoking had greater adverse effects on the serum lipid profile as compared to bidi smoking and tobacco chewing thereby increasing the cardiovascular risk.

\section{References}

1. Gokhle B G. Tobacco in seventeenth century India. Agricultural history.1974. 48(4):484-492.

2. Mohamed S, Ibrahim A, and Joyce Y.G. Clinical Methods: The History, Physical and Laboratory examination. Chapter 40 : Tobacco use. $3^{\text {rd }}$ edition. Boston: Butteworths: 1990.

3. Jha P, Chaloupka F J, Curbing the Epidemic Governments and the Economics of Tobacco control. Washington, D.C. A World Bank Publication;1995.

4. Executive summary of the third report of the National Cholesterol Education Program (NCEP). Expert Panel on detection, evaluation, and treatment of high blood cholesterol in Adults (Adults treatment panel III) JAMA . 2001; 285 (19):2486-97.

5. Allain C C, Poon L S, Clen C S G, Richmond $\mathrm{W}, \mathrm{Fu} \mathrm{P}$ C. Enzymatic determination of total serum cholesterol. Clin.Chem.1974.20:470-75.

6. Fossati P, Prencipe L. Serum triglycerides determined colorimetrically with an enzyme that produces hydrogen peroxide. Clin Chem.1982. 28(10):2077-80.

7. Finley P R, Schifman R B, Williums R J, Lichti D A. Cholesterol in high-density lipoprotein: use of $\mathrm{Mg}+$ / dextran surface in its enzymatic measurement. Clin.Chem. 1978. 24(6):931-933.

8. Friedwald W T. Levy R I, Fredrickson D S. Estimation of the concentration of low density lipoprotein cholesterol in plasma without use of the preparative ultracentrifuge. Clin Chem.1972. 18:499-509.
9. Teruo I. Cigarette smoking as risk factors of coronary artery disease and effects on platelets function. Tobacco Induced diseases.2004. 2(1):27-33.

10. Huxley R, Woodward M. Cigarette smoking as a risk factors for coronary heart disease in women compared with men : a systemic review and meta-analysis of prospective cohort studies. Lancet. 2011.378(9799):1297-1305.

11. Prabha V, Waheeda S, Meriton S A.. Effect of tobacco smoking on lipid profile. Indian Journal of applied research, 2015. 5(3):562-564.

12. Patel K, Prajapati P, Sanghavi S, Goplani V. A study on effects of cigarette smoking on blood cholesterol in young population of Ahmedabad. IJBAP. 2014.3(1):106110.

13. Sriniwas R and Emmanuel S Y. The effect of chronic Tobacco Smoking and Chewing on the profile. J Clin Diagn Res. 2013. $7(1): 31-34$. 